\title{
Characteristics of Mexican women admitted to emergency care units. Alcohol consumption and related problems
}

\author{
Martha Romero, PhD, (1) Liliana Mondragón, Psych, ${ }^{(1)}$ Cheryl Cherpitel, PhD, ${ }^{(2)}$ \\ Ma. Elena Medina-Mora, PhD, (1) G uilherme Borges, ScD. ${ }^{(1,3)}$
}

\begin{abstract}
Romero M, Mondragón L, Cherpitel C, Medina-Mora E, Borges G. Characteristics of Mexican women admitted to emergency care units. Alcohol consumption and related problems. Salud Publica Mex 2001;43:537-543. The English version of this paper is available too at: http://www.insp.mx/salud/index.html
\end{abstract}

\begin{abstract}
A bstract
Objective. This article describes the demographic characteristics and psychological differences in a sample of female heavy and non-heavy drinkers who attended three emergency services of the Mexican city of Pachuca, Hidalgo. Material and Methods.A sample of patients seen at emergency services (ES) patients over the age of 18 was selected using ES admission forms. Twenty-five-minute, face-to-face interviews were conducted by a gro up of trained interviewers. Patients answered various questionnaires and scales to measure alcohol consumption and to provide information on variables that have proved to be related to female drinking. Results. Thirty-six women (5.2\%) out of 717 of the total number of women were found to be heavy drinkers according to the TW EAK scale. This group of women had 2.3 times the risk of becoming depressed, 2.87 times the risk of taking other drugs, 1.95 times the likelihood of having been sexually abused and 1.57 times the risk of displaying suicidal ideation. Conclusions. Data from this small analysis confirm international findings that problem drinking among females throughout the life cycle is linked to depression. As regards the screening instruments employed, it is necessary to conduct more in-depth research to enrich their contents and increase their reliability and validity when used among female populations. In this study, the TW EAK
\end{abstract}

\author{
Romero M, Mondragón L, Cherpitel C, \\ Medina-Mora E, Borges G. \\ Características de mujeres mexicanas que asisten \\ a servicios de urgencias. \\ Consumo de alcohol y problemas relacionados. \\ Salud Publica Mex 2001;43:537-543. \\ El texto completo en inglés de este artículo también \\ está disponible en: http://www.insp.mx/salud/index.html
}

\section{Resumen}

Objetivo. El presente artículo de investigación describe las características demográficas y las diferencias psicológicas en una muestra de mujeres con consumo alto y consumo no-alto de alcohol, que asistieron a tres servicios de urgencias localizados en la ciudad mexicana de Pachuca, Hidalgo. Material y métodos. Una muestra de las pacientes mayores de 18 años que asistieron al servicio de urgencias fue seleccio nada utilizando las formas de admisión. Se hicieron entrevistas cara a cara de 25 minutos de duración por un grupo de entrevistadores capacitados. Las pacientes contestaron diferentes instrumentos para medir el consumo de alcohol y escalas de otras variables que se sabe pueden relacionarse con el consumo femenino de alcohol. Resultados. Treinta y seis mujeres (5.2\%) de un total de 717 fueron calificadas como bebedoras con consumo alto de alcohol de acuerdo con la escala deTW EAK. Presentaron 2.3 veces mayor riesgo de estar deprimidas, 2.87 de consumir otras drogas, 1.95 de haber sido víctimas de abuso sexual y 1.57 de presentar ideación suicida. Conclusiones. Los resultados de la investigación confirman que el consumo de alcohol en las mujeres a lo largo del ciclo vital está ligado a la depresión. En relación con los instrumentos de tamizaje utilizados, es necesario conducir mayor número de investigaciones en profundidad para enriquecer sus contenidos y

This study was supported by the National Council on Science and Technology, the Ministry of Health No. MO 148H 9602, the Mexican Institute of Psychiatry N 0.4271 and a grant from the N ational Institute on Alcohol A buse and Alcoholism R21 AA11503.

(1) Dirección de Investigaciones Epidemiológicas y Sociales, Instituto N acional de Psiquiatría Ramón de la Fuente. México, D.F., México.

(2) Centro de Investigación en Alcohol. Alcohol Research G roup, Berkeley, California, Estados U nidos de América.

(3) Universidad Autónoma Metropolitana-X ochimilco, México, D.F., México.

Received on: September 13,2000 • Accepted on: June 15, 2001

Address reprint requests to: D ra. Martha Romero M. Instituto N acional de Psiquiatría, Dirección de Investigaciones Epidemiológicas y Sociales. Calzada México-Xochimilco 101, colonia San Lorenzo Huipulco,Tlalpan, 14370 México, D .F., México.

E-mail: romerom@ imp.edu.mx 
proved to be extremely useful for studies in emergency services.The English version of this paper is available to 0 at: http://www.insp.mx/salud/index.html

Key words: alcohol, drinking; women; emergency medical services; Mexico aumentar su confiabilidad y validez al utilizarlos con poblaciones femeninas. En este estudio, el TW EAK probó ser de gran utilidad para su uso en los estudios de los servicios de emergencia. El texto completo en inglés de este artículo también está disponible en: http://www.insp.mx/salud/ index.html

Palabras clave: consumo de bebidas alcohólicas; mujeres; servicios médicos de urgencia; México
$\mathbf{R}$ esearch on women's health has led to an increased $\mathbf{R}$ interest in women's lives and living conditions. Alcohol research has assessed the role of alcohol consumption and inebriation in women's health and life changes resulting from it. The age of onset of alcohol consumption in women has decreased, meaning that there is a larger proportion of adult women who began to drink alcohol in their youth. ${ }^{1}$ Early detection of women who abuse alcohol ${ }^{2}$ poses an additional problem.

International studies on women's health show that female alcohol abuse is associated with depression throughout life. Evidence supporting the link between alcohol abuse and depression in women is found in epidemiological as well as clinical sources. ${ }^{3,4}$

Regarding marital status, it has been found that never-married, divorced, and separated women generally have the highest rates of heavy drinking and drinking-related problems, while married women have intermediate rates and widows have the lowest rates. ${ }^{5-7}$

When compared with men, women with drinking problems are also more likely to be depressed, have low self-esteem, alcohol-related physical problems, marital discord or divorce, husbands with alcohol problems, a history of sexual abuse, and to abuse alcohol in response to life crises. ${ }^{8}$

In this respect, little is known in Mexico about gender differences of alcoholism; in other words; what makes women who drink moderately different from those whose consumption is risky? and how do these differences become manifest in women living in semi-urban communities where cultural norms concerning drinking are more rigid?

In studies carried out in emergency services, it is commonly found that women only constitute a small proportion of the sample studied, or that statistical analyses by gender are not feasible due to the small size of the sample. In fact, women who abuse alcohol do have features in common with male alco- hol users, and may undergo alcohol-related problems requiring emergency care.

The purpose of this study was to explore and describe demographic and psychological differences (depression, self-esteem, suicidal ideation, sexual abuse and drug use) in a sample of female heavy and nonheavy drinkers who attended an emergency service in the City of Pachuca, Hidalgo, Mexico.

\section{Material and Methods}

The study was conducted from October 1996 to August 1997. A probability sample of emergency room patients over age 18 was selected from the Emergency Service (ES) admission registry. Patients were selected from each of the three main hospital emergency services in Pachuca, Hidalgo, and were representative of all types of ESs available in that city: Secretaría de Salud (SSA), Instituto Mexicano del Seguro Social (IMSS), and Instituto de Seguridad y Servicios Sociales de los Trabajadores del Estado (ISSSTE).

Previous informed consent interviews were conducted immediately after a patient had been selected. Of 1624 patients sampled in Pachuca during a fourmonth period (1996-1997), 93\% ( $n=1511)$ agreed to participate. The non-interview rate did not significantly differ across the ES sample. Those not interviewed were likely to be older than those interviewed, but there were no differences by gender. Of those who were not interviewed, $5 \%$ refused to participate, $1 \%$ left the hospital prior to completing the interview, and another $1 \%$ were unable to be interviewed due to their medical condition. Further details on the study methods have been published previously. ${ }^{9}$

A twenty-five minute long face-to-face interview was conducted by a staff of interviewers trained and supervised by the authors, in their respective locations. Sociodemographic data were obtained and, patients were asked about the injury or illness that prompted them to seek emergency care. We used several screen- 
ing instruments for detecting problem drinking among women:

- CAGE. ${ }^{10, *}$

- Brief MAST ${ }^{11}$ is a 10 -item subset of the original 25-item MAST (Michigan Alcoholism Screening Test. $^{12}$

- AUDIT (Alcohol Use Disorder Identification Test)..$^{13}$

- $T_{W E A K}{ }^{14}$ is an acronym for Tolerance (number of drinks to feel high; number of drinks one can stand), Worry about drinking, Eye-opener (morning drinking), Amnesia (blackouts), and Cut down on drinking $(\mathrm{K} / \mathrm{C})$.

- Having five or more drinks on one occasion.

All but the TWEAK scale were developed for male alcoholics (such as the CAGE) or for a group of both male and female patients in primary care settings (such as the AUDIT). The TWEAK is the only instrument developed specifically for women.

We also used a diagnostic instrument based on ICD-10 and DSM-IV criteria for both alcohol dependence and harmful drinking/abuse from the Alcohol section of the CIDI (Composite International Diagnostic Interview) core. ${ }^{15}$

Other scales were applied to obtain information on a number of variables that have been found in several studies to be related to female drinking:

Suicidal Ideation Scale. Includes four closed items, as follows: Have you experienced the feeling that life is worthless? Have you been in a situation where you wished you didn't exist anymore? Have you thought it would be better to die? Have you ever tried to kill yourself? Women who gave affirmative answers to at least one item were regarded as suicidal ideation cases. This scale has been used in various studies conducted on the Mexican population. ${ }^{16}$ The results of a factor analysis completed by using three of these items yielded one factor that accounted for $70.1 \%$ of variance. The internal consistency of the scales was good, as evidenced by a Cronbach's alpha value of 0.78 .

Depression Scale. This instrument, consisting of twenty items from the CES-D, ${ }^{17}$ assesses depressive symptoms. In this section, behaviors and feelings of depression present one week before application were registered. ${ }^{18}$

\footnotetext{
* C: cut-down

A: annoyed

G: guilty

E: eye-opened
}

For case status definition, we used the mean plus one standard deviation ( $\bar{X}=11.46$, SD:10.7). Patients above this level were considered cases of depression.

Alcohol Use. Refers to a person's drinking pattern during the past twelve months. A number of drinking pattern categories applicable to the general population were defined using information gathered through selfreports on the usual frequency of drinking and on the usual quantity of alcohol consumed.

After this procedure was completed, a modified drinking pattern was designed on the basis of the recommendations given by the World Health Organization, to define what should be considered as heavy drinking in women, ${ }^{*}$ The final drinking pattern was defined as follows:

Abstainers. Drinks less than once a year or has never drunk.

Low quantity infrequent drinker. Drinks from once a year to once a month and never drinks more than four drinks on any occasion.

High quantity infrequent drinker. Drinks from once a year to once a month. During the past year, drank five or more drinks on one or more occasions.

Low quantity frequent drinker. Drinks two or three times a month to once or twice a week, three or four times a month or daily, but never drinks more than four drinks per occasion.

High quantity frequent drinker. Drinks two or three times a month or daily, and drinks from five to nine drinks per occasion.

Frequent heavy drinker. Drinks from three to four times a month or daily, consuming ten or more drinks per occasion.

Drug use. The use of drugs such as amphetamines, stimulants, marihuana, cocaine/crack, hallucinogens, inhalants, and medical drugs without a prescription during the last 12 months was explored in this section. Sexual abuse. This section includes three questions: 1) Have you ever been sexually abused? Possible answers included: "no," "yes, as a child," "yes, as a teenager," and "yes, as an adult," while the aggressor might have been a relative, a friend, a friend of the family, or a stranger. The remaining questions were: 2) How often were you abused? and 3) How did the abuse affect you?

Marital violence. Different scales specially designed for the study were used to identify women who had been subject to domestic violence.

\footnotetext{
* The intake of 5 or more drinks per occasion is considered heavy drinking. Each standard drink contains 12 grs. of pure alcohol (Babor \& Grant 1992).
} 
Self-esteem. The scale developed by Rosenberg ${ }^{19}$ was used to approach this issue. This instrument consists of two dimensions that measure positive and negative aspects of self-esteem. The version used for this study consists of 10 Likert-scale items proposed by Rosenberg, where $1=$ total agreement and $4=$ total disagreement. According to these possible answers, the higher the score, the higher the respondent's self-esteem.

Following Gudmunsdottir, ${ }^{20}$ four additional items designed by Knupfer and Room ${ }^{21}$ were added as well as Room's six-item control scale. ${ }^{22}$ All ten items have the same answer options as those on Rosenberg's scale.

We present basic descriptive frequencies of alcohol consumption for the total sample and cross-tabulations of alcohol consumption patterns according to the results from the TWEAK scale (see below), for the main reason for admission and sociodemographic variables. Chi-square tests and Fisher exact tests were used for this part of the analysis. We also performed a series of univariate and multiple logistic regression analyses modeling the TWEAK positive status and several potential risk factors. Prevalence odds ratios and $95 \%$ confidence intervals are reported in this part of the analysis.

\section{Results}

The sample consisted of 1,624 patients admitted to the emergency services of the three hospitals. One thousand $511,47 \%(n=717)$ of the patients were women, who agreed to take part in the study. The distribution of the female group according to their drinking pattern shows

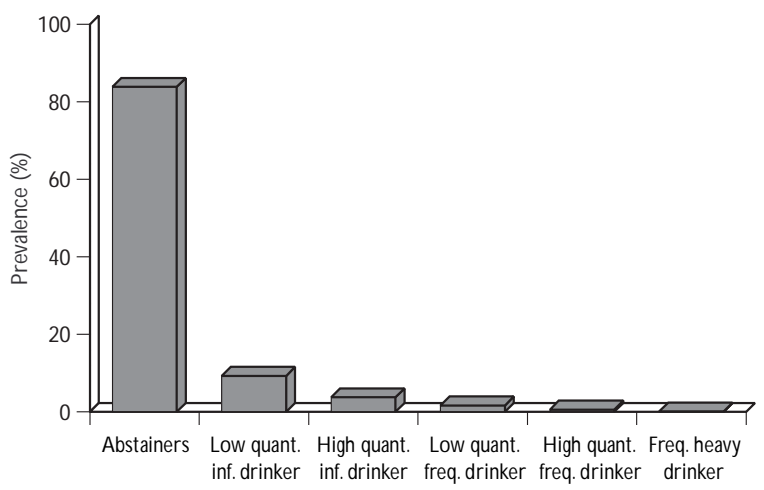

Figure 1. Alcohol consumption pattern in a sample OF WOMEN ATTENDING THREE EMERGENCY ROOMS IN Pachuca, Hidalgo, México, 1996-1997 that a high percentage of women described themselves as abstainers (83.9\%) (Figure 1). Regarding the reason for their admission, differences were found in relation to their consumption patterns $\left(\chi^{2}=17.4, p=0.066\right)$. About $0.4 \%$ of the women admitted due to medical problems had moderate/high consumption, while $1.0 \%$ and $3.0 \%$ of women admitted as a result of accidents and violence displayed these consumption levels, respectively (Table I).

We inspected several of our screening instruments to find out which one performed best for women. Similar to the CAGE and the 10-item brief MAST, the TWEAK identified most known alcoholics, but it showed a higher sensitivity and specificity than the CAGE and B-MAST in detecting alcoholism/heavy drinking women in the emergency services. Different cut-off values are recommended for screening different populations. Based on previous reports of this sample, a cut-off point $=2$ was selected as the most reliable value for distinguishing female heavy drinkers from low-risk female drinkers. ${ }^{23-25}$ Although only 5.2\% of the women in our sample of ES attendees $(n=36)$ were found to be TWEAK positive, this percentage was higher than those obtained using other instruments

Table I

\section{Alcohol CONSUmption pattern and main REASON for admission. Pachuca, Hidalgo, México, 1996-1997}

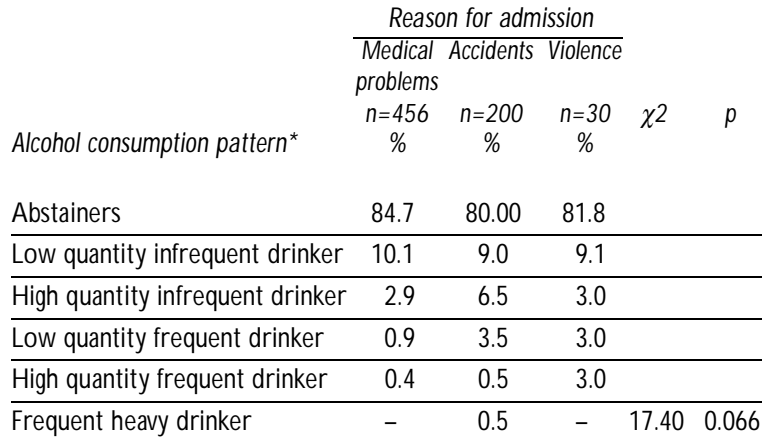

* 28 patients had missing data on alcohol consumption pattern Abstainer: drinks less than once a year or has never drunk. Low quantity infrequent drinker: drinks from once a year to once a month and never drinks more than four drinks in any occasion.

High quantity infrequent drinker: D rinks fromn once a year to once a mont. During the past year, drank five or more drinks on one or more ocassions.

Low quantity frequent drinker: $D$ rinks from tow or three times a month to once or twice a week, three or four times a month or daily, but never drinks more than four drinks on any ocassion.

High quantity frequent drinker: Drinks two or three times a month or daily, and drinks from five to nine drinks per occasion.

Frequent heavy drinker: Drinks from three to four times a month or daily, consuming ten or more drinks on each occasion. 
(1.0\% for the BMAST, $1.2 \%$ for the Trauma Scale, $1.4 \%$ for the AUDIT, $2.9 \%$ for the CAGE, or $2.0 \%$ for the CIDI).

Most of TWEAK-positive women were aged between 30 and 49 years (55.5\%). As for their marital status, women who lived on their own but had had a partner ever (living with a partner, separated, divorced, and widowed) were, as a whole, the TWEAK-positive group. The same was observed for the group with higher educational attainment (37.1\%) (Table II).

As shown in Table III, 28.5\% of TWEAK-positive women displayed depressive symptoms, while only $14.7 \%$ of TWEAK-negative women did, a difference that was statistically significant $(p=0.02)$. Also, TWEAK-positive women had higher prevalence of suicidal ideation $(25.7 \%)$, though statistical differences were not found. In relation to sexual abuse, 7.1\% of the women who were TWEAK-positive reported

Table II

Sample distribution according to tWeak status AND SOCIODEMOGRAPHIC CHARACTERISTICS. Pachuca, Hidalgo, México, 1996-1997

\begin{tabular}{|c|c|c|c|c|}
\hline & \multicolumn{2}{|c|}{ Tweak* } & \multirow[b]{2}{*}{$\chi 2$} & \multirow[b]{2}{*}{$p$} \\
\hline & $\begin{array}{c}\text { Negative } \\
n=653 \\
\%\end{array}$ & $\begin{array}{c}\text { Positive } \\
n=36 \\
\%\end{array}$ & & \\
\hline \multicolumn{5}{|l|}{ Demographic } \\
\hline \multicolumn{5}{|l|}{ Age } \\
\hline $18-29$ & 37.8 & 27.7 & & \\
\hline $30-49$ & 45.1 & 55.5 & & \\
\hline $50-65$ & 16.9 & 16.6 & 1.72 & 0.421 \\
\hline
\end{tabular}

Civil status

\begin{tabular}{lrrrl} 
Single & 22.3 & 22.8 & & \\
\hline Married & 55.3 & 37.1 & & \\
\hline Common-Law & 9.6 & 20.0 & & \\
\hline Separated & 9.7 & 2.9 & & \\
\hline Divorced & 2.3 & 2.8 & & \\
\hline W idowed & 5.2 & 14.2 & 10.63 & 0.059
\end{tabular}

Educational level

\begin{tabular}{lrrrrl} 
W ithout formal education & 7.7 & 17.1 & & \\
\hline Primary School & 27.3 & 17.1 & & \\
\hline Secondary School & 19.0 & 8.6 & & \\
\hline High School & 29.5 & 37.1 & & \\
\hline University/Postgraduate & 16.5 & 20.0 & 7.72 & 0.102
\end{tabular}

Main reason for admission

\begin{tabular}{lrrrl} 
Accidents & 27.8 & 50.0 & & \\
\hline Violence & 4.5 & 8.3 & & \\
\hline Medical Problems & 67.5 & 41.6 & 10.20 & 0.006 \\
\hline
\end{tabular}

Table III

Sample distribution according to tweak status AND SELECTED FACTORS. Pachuca, Hidalgo, México, 1996-1997

\begin{tabular}{|c|c|c|c|c|c|c|}
\hline & \multicolumn{2}{|c|}{ Tweak* } & \multirow{3}{*}{ Odds ratio } & \multirow{3}{*}{ IC-95\% } & \multirow{3}{*}{$\chi^{2}$} & \multirow{3}{*}{$p$} \\
\hline & $\begin{array}{c}\text { Negative } \\
n=653\end{array}$ & $\begin{array}{c}\begin{array}{c}\text { Positive } \\
n=36\end{array}\end{array}$ & & & & \\
\hline & $\%$ & $\%$ & & & & \\
\hline \multicolumn{7}{|c|}{ Depression } \\
\hline No & 85.2 & 71.4 & 1 & & & \\
\hline Yes & 14.7 & 28.5 & 2.31 & $1.07-4.97$ & 4.87 & 0.0 \\
\hline
\end{tabular}

Suicidal ideation

\begin{tabular}{lllllll} 
No & 81.4 & 74.2 & 1 & & & \\
\hline Yes & 18.5 & 25.7 & 1.52 & $0.69-3.33$ & 1.12 & 0.288
\end{tabular}

Self-esteem

\begin{tabular}{lllllll} 
High & 14.2 & 20.0 & 1 & & & \\
\hline Low & 85.7 & 80.0 & 0.66 & $0.28-1.57$ & 0.87 & 0.350
\end{tabular}

Sexual abuse

\begin{tabular}{rrrllll} 
No & 96.2 & 92.8 & 1 & & & \\
\hline Yes & 3.7 & 7.1 & 1.95 & $0.43-8.76$ & 0.80 & 0.369
\end{tabular}

Drugs

\begin{tabular}{rrrrrrr} 
No & 96.9 & 91.7 & 1 & & & \\
\hline Yes & 3.1 & 8.3 & 2.87 & $0.81-10.17$ & 2.93 & 01.087
\end{tabular}

$n=717$

having been sexually abused. Nevertheless, as in the other variables, these differences were not significant. In relation to other drug use, $8.3 \%$ of TWEAK-positive women used drugs, compared with $3.1 \%$ of TWEAKnegative women $\left(\chi^{2}=2.93, p=0.087\right)$.

Results of a univariate logistic regression model are also shown in Table III. It was found that TWEAK positive women had 2.31 times the risk of having depression, 2.87 times the risk of taking other drugs and were 1.95 times as likely to have been sexually abused (Table III). Women with low levels of self-esteem were less likely to be TWEAK-positive (odds ratio $[O R]=0.66$ ). A multiple logistic regression model was constructed using TWEAK as the dependent variable and all the risk factors in Table III, plus age, as the independent variables. Compared to the results in Table III, the estimates were lower for depression $(\mathrm{OR}=2.2)$, suicidal ideation $(\mathrm{OR}=1.1)$, sexual abuse $(\mathrm{OR}=1.4)$, and drug use (1.8), but increased slightly for self-esteem $(\mathrm{OR}=0.6)$ (data not shown). As expected, confidence intervals were wider and included the null value for depression.

As seen in Table IV, TWEAK-positive women are more likely to have a moderate- or heavy-drinking 
Table IV

Sample distribution according to tweak status AND PARTNER'S ALCOHOL CONSUMPTION. Pachuca, Hidalgo, México, 1996-1997

\begin{tabular}{ccc} 
& \multicolumn{2}{c}{ Tweak* } \\
\cline { 2 - 3 } Partner's alcohol consumption $\ddagger$ & Negative & Positive \\
& $n=653$ & $n=36$ \\
$\%$ & $\%$
\end{tabular}

\begin{tabular}{lrc} 
Abstainers & 22.8 & - \\
\hline Rehabilitated alcoholic & 2.6 & - \\
\hline Moderate & 62.0 & 58.3 \\
\hline O ccasional heavy & 7.8 & 41.7 \\
\hline Excessive & 4.9 & -
\end{tabular}

Fisher's exact test $=0.009$

* 28 patients had missing data on TW EAK status

‡ Based on women's perception

partner rather than to share their lives with someone who abstains from alcohol (Fisher exact test=0.009).

None of the thirty-six women who drink heavily was admitted to the emergency room as a result of domestic violence. Finally, ten out of the thirty-six TWEAK positive women fulfilled DSM-IV criteria for alcohol abuse and alcohol dependence.

\section{Discussion}

The analyses of alcohol use among women admitted to emergency services in Pachuca, Hidalgo, seem to support some findings reported in the international literature.

Although the National Surveys on Addictions 26,27 show a general upward trend in female alcohol use, the data presented here indicate that cultural aspects might influence changes in women's drinking pattern, which might also be explained by the growth of the urban population.

Abstinence in women in Pachuca is higher than that found in the National Household Surveys (89\% vs $66 \%$ ). In these women traditions are extremely important.

Local studies conducted in Mexico* have shown that in present-day Mexico, norms are more related to approving who may drink than to promoting mode-

\footnotetext{
* Medina-Mora ME. El abuso de alcohol: antecedentes y consecuencias: evaluación de un modelo de intervención. Resultados de la Fase I, February 1997.
}

ration. It is believed that females should not drink. Occasional inebriation among males is considered normal, whereas females are not supposed to drink. Both males and females, young and old persons support these double standards. The importance of these beliefs is reflected in the high percentage of women who do not drink and have never gotten drunk.

As regards the screening instruments employed, it is necessary to conduct more in-depth research to enrich their contents and increase their reliability and validity when used among female populations. In this study, the TWEAK proved to be extremely useful for studies in emergency services.

On the other hand, according to Gomberg, 3 problem drinking among females is linked to depression throughout the life cycle. Data from this brief analysis confirm international findings. However, further studies are necessary to know which women began drinking earliest, since it is also mentioned that female problem drinkers who report preexisting depression differ from primary problem drinkers in the following aspects: They have a family history less positive to problem drinking; a shorter history of problem drinking, and a more favorable prognosis. Also, crossscreening (depression-alcohol) seems to be useful for early detection of problem drinking.

Results related to self-esteem are worth mentioning, since they differ from what has been reported in the international literature. In this study, high-risk female drinkers obtained higher scores in self-esteem $(20 \%)$, compared with women with negative TWEAK $(14.2 \%)$. Could alcohol use be regarded as a form of self-assurance, independence, and greater autonomy? or is it the effect of denial, a characteristic symptom of people with abuse or addiction problems? This aspect must be studied in depth through qualitative methodology.

In this study we only included few questions regarding sexual abuse and asked little about emotional and physical abuse in childhood. The correlation between alcohol abuse and sexual abuse might have been higher. Langeland and Hartgers ${ }^{28}$ suggest some methodological issues for improving results. These include the method used (questionnaires tend to obtain lower rates than interviews), the number of questions and their contents, how specific the definition of abuse is and the age of the aggressor and the victim at the time of the occurrence. In the future, more specific scales could be included.

Traditionally, women of all ages are responsible for controlling their men's drinking while at the same time controlling their own. Nevertheless, it has been pointed out that the most significant relation- 
ship in the lives of chemically dependent women is often with an addictive partner. ${ }^{29}$ The strong consenting relationship between a couple's drinking together with the stress of life with "a significant other," and having to combine extremely diverse expectations in addition to coping with several daily problems including their own consumption ${ }^{30}$ have also been considered as important factors. Research findings related to the role of drinking in the couple seem to confirm international findings.

Finally, for better results, it is suggested that only women should interview women, since Pollner ${ }^{31}$ suggests that gender may play an important role in mental health interviews. Male and female respondents interviewed by women report more symptoms of depression, substance abuse and behavior disorders than respondents interviewed by men.

Two limitations of this study are worth mentioning. First, it is a cross-sectional survey and it is not possible to draw any firm causal statement about the relation between our variables. Second, we found only a small prevalence of heavy-drinkers (TWEAK-positive) women and our results lack high statistical power, as evidence by our wide confidence intervals. Future research should include at least retrospective information about the variables and a sufficient number of women who are heavy drinkers.

\section{References}

1. Secretaría de Salud/C onsejo Nacional contra las Adicciones. El consumo de drogas en México. Diagnóstico, tendencias, acciones. México, D .F.: SSA/C onadic, 1999

2. Campillo C, Díaz R, Romero M, C errud J,Villatoro J. Mexico C ity chapter. En: Babor, T, Grant M, ed. Project on identification and management of alcohol-related problems. Report on Phase II.A randomized clinical trial of brief intervention in primary health care. Ginebra: World Health $0 \mathrm{r}$ ganization, 1992.

3. Gomberg-Lisansky E. Risk factors for drinking over a woman's life span. Alcohol Health Res World 1994;18(3):220-227.

4.W ilsnack Sh,W ilsnack R, Hiller-Sturmhofel S. How women drink. Epidemiology of women's drinking and problem drinking. Alcohol Health Res World 1994;18(3):173-181.

5. Glass-C rome IB. Gender-related issues in alcohol problems research-A special need group. En:Tabakoff \& Hoffmann, ed. Biological aspects of alcoholism. Implications for prevention, treatment and policy. Seattle (WA): Hogrefe \& Huber Pub, 1995:163-176.

6. Anderson P. Alcohol and risk of physical harm. Cancer of the female breast. En: Holder H, Edwards G, ed. Alcohol and public policy. Evidence and issues. 0 xford (UK): 0 xford University Press, 1995:82-103.

7. Romero M, Villatoro J, Medina-Mora M. Alcohol consumption among Mexican women: Implications of a syncretic culture. 24th Annual Alcohol Epidemiology Symposium, 1998; Florence, Italy.
8. McC aul M, Furst J. Alcoholism treatment in the U nited States. Alcohol Health Res W orld 1994;18(4):253-260.

9. Borges C, Medina-Mora ME, Cherpitel C, Casanova L, Mondragón L, Romero M. Consumo de bebidas alcohólicas en pacientes de los servicios de urgencias de la ciudad de Pachuca, Hidalgo. Salud Publica Mex 1999:41(1):3-11.

10. Ewing JA. D etecting alcoholism: The CAGE questionnaire. JAMA 1984;252:1905-1907.

11. G ibbs LE.Validity and reliability of the Michigan Alcoholism Screening Test:A review. D rug Alcohol Depend 1983;12:279-285.

12. Selzer M.The Michigan Alcoholism ScreeningTest:The quest for a new diagnostic instrument. Am J Psychiatry 1971;127:1653-1658.

13. Babor Th, De La Fuente Jr, Saunders J, G rant M. AUDIT:The alcohol use diso rders identification test. G inebra:W orld Health 0 rganization, 1989. 14. Russell M, Martier S, Sokol R, Mudar P, Bottoms S, Jacobson $S$ et al. Screening for pregnancy risk-drinking. Alcohol Clin Exp Res 1994;18: 1156-1161.

15. W orld Health 0 rganization. CIDI core (C omposite International Diagnostic Interview) Authorized Core Version 1.1. Ginebra:W orld Health O rganization, 1993.

16. G onzález-Forteza C, Andrade P. La relación de los hijos con sus progenitores y sus recursos de apoyo: correlación con la sintomatología depresiva y la ideación suicida en los adolescentes mexicanos. Salud Mental 1995;18(4):41-48.

17. Radloff LThe CES-D Scale:A self-report depression scale for research in the general population.Appl Psychol Meas 1977;1:385-401.

18. G onzález-Forteza C. Factores protectores y de riesgo de depresión e intentos de suicidio en adolescentes. Tesis de doctorado. México, D.F.: Universidad N acional Autónoma de México, Facultad de Psicología, 1996. 19. Rosenberg M. The Rosenberg Self-Esteem Scale. Maryland (MD):The Morris Rosenberg Foundation c/0 D ept of Sociology, University of Maryland, 2000. Disponible en: http://www.bsos.umd.edu/socy/rosenberg.htm. 20. Gudmundsdottir A.W omen seeking treatment, alcohol abuse and psychological problems. 20th Annual A lcohol Epidemiology Symposium; 1994; Rüschlikon, Switzerland.

21. Knufer G, Room R. Abstainers in a metropolitan community. Q uart J Stud Alc 1969;31(1):108-131.

22. Kaskutas LA.An analysis of "W omen for sobriety". D octoral dissertation. San Francisco (CA): U niversity of C alifornia, Berkeley, 1992.

23. Cherpitel $C h$, Borges $G$. Comparison of cut-off point for screening instruments for alcohol problems between Mexican American and Mexican patients in the ER. Subst Use Misuse 200;35(10)1419-1430.

24. Cherpitel $\mathrm{Ch}$, Borges $\mathrm{G}$. Performance of screening instruments for alcohol problems in the ER: A comparison of Mexican Americans and Mexicans in Mexico.Am J D rug A lcohol A buse 2000;26(4):683-702.

25. Bradley K, Boy-W ickizer J, Powell S, Burnman M. Alcohol screening questionnaires in women. A critical review. JAMA 1998;280(2):166-171.

26. Secretaría de Salud. Encuesta N acional de Adicciones 1990. México, D.F.: SSA, 1990.

27. Secretaría de Salud. Encuesta N acional de Adicciones 1993. México, D.F.: SSA, 1993.

28. Langeland W, Hartgers $\mathrm{Ch}$. Child sexual and physical abuse and alcoholism:A review.J Stud Alcohol 1998; 59(May): 336-348.

29. Kauffman E, Morrison D., N eson-Zlupko L The role of women's therapy groups in the treatment of chemical dependence. Am J 0 rthpsychiat 1995;65(3):355-363.

30. Gudmunsdottir A. Social and emotional problems of women in alcoholism treatment. Paper presented at the 25th Annual Alcohol Epidemiology Symposium; 1999 May 30-June 4; Montreal, Canadá.

31. Pollner $M$. The effects of interviewer gender in mental health interviews. J N ervous Mental D is 1998;186(6):369-373. 